its deliberations breadth and understanding is now an impossibility. At the same time, it would seem desirable that the intermission of activity should not be complete. It is generally conceded that the time for planning for peace is now, and not at the close of hostilities. This applies no less to Africa than to Europe. A planning that begins with the peace will be too late to cope with the changes in African societies, which if the aftermath of the War of $1914-18$ is a criterion, will ensue all too rapidly.

\section{Storage of Electric Power in the Ruhr}

THERe has been a rapid increase in recent years in the use of electricity in steel manufacture in Germany. This 'electric steel' has a very uniform structure, but, if the cost is to be comparable with that produced by other means, the factor of safety has to be reduced. With so many high-frequency furnaces going intermittently, the power supply systems must be subjected to considerable peak demands. This is especially the case in the Ruhr, where, although there is a plentiful supply of coal, considerable reliance is placed upon the watergenerated supplies from Austria to meet the heavy peak demands. The largest and one of the most interesting of the storage stations is situated at Herdecke on the banks of the Rhine about six miles south of Dortmund and nearly twenty miles east of Essen. It is connected with the control point at Brauweiler, which is on the Rhine between Cologne and Dusseldorf. By accumulating water in an elevated reservoir by means of pumps and the erection of the Herdecke power storage station and others in the district, the peak-load problem has been solved satisfactorily. Interesting details of this station are given in the Electrician of July 26.

The upper reservoir of the Herdecke plant, covering an area of 18 acres, is designed to permit the full development of the available power. The maximum variation in water-level from empty to full is $65 \mathrm{ft}$. The maximum pressure head between the lower reservoir, Lake Hengsty, and a full upper reservoir is $540 \mathrm{ft}$., and the minimum head available is thus $475 \mathrm{ft}$. The power house is $500 \mathrm{ft}$. in length and each machine has an axial length of $85 \mathrm{ft}$. The station can be automatically switched from pumping to turbine operation in two minutes, and during pumping the turbine discharges are closed by means of flaps. The upper reservoir is oval in shape and is about $800 \mathrm{ft}$. above sea-level; this necessitated the excavation of $1,300,000$ cubic yards of rock. The entire concrete surfaces coming into contact with water have been rendered impervious by means of a bitumen spray treatment. The work was commenced at the beginning of September 1927, and the station was brought into partial operation in December 1929, full operation following about a year later. The characteristic feature of this type of station is that at times of low power consumption the waste current of the water stations, or the increased night output of the steam stations, is employed to pump water back into the storage reservoir.

\section{This Season's English Herbs}

More than usual interest will be shown this season in the English harvests of vegetable drugs, and it is now possible to judge from reports by herb farmers on the prospects of their crops what the harvests are likely to be, pro vided weather conditions for collection are favourable. Fair supplies are promised of those old-fashioned medicines such as hyssop, rue, wormwood, comfrey, balm and dill, but the same cannot be said of chamomile, the prospects of which are disappointing, an outlook that is all the more unfortunate since it is impossible to obtain supplies from Belgium. Indeed, it would seem that those who have pinned their faith, in the past, to chamomile tea will have to try one of the more modern remedies which are not so scarce. What is still more unfortunate is that on some herb farms the severe frost last winter destroyed the main belladonna plantations so that very little leaf-which is so badly wanted because of the absence of imports of the Continental plant-could be collected this season. It is satisfactory to know that the young belladonna plants of this year's sowing are looking well.

Growers of henbane report that there was a good crop of second-year biennial plants, and leaf and flower of good alkaloidal content have been harvested ; after a time of drought, rain came to save the firstyear seedlings, which will provide leaves for autumn drying. Prospects of a crop of high-testing digitalis leaf are favourable. Aconite is said to be looking well and there is a full crop of valerian. Having regard to the stoppage of supplies of lavender oil distilled in the Grasse district of the Alpes Maritimes, it is well to learn that English lavender plants stood up well to the hard winter and the flowers have bloomed earlier and, in some cases, better than usual ; a fair yield of English lavender oil may be expected for this season; more of the flowers will go to the still and less to Covent Garden in bunches for street vendors, and thus at least part of the shortage due to the lack of French oil will be made good.

\section{Notation for Tapping Systems of the Rubber Tree}

THe scientific groups dealing with rubber production in Ceylon, Malaya and Netherlands East Indies have recently adopted a common notation for expressing the varied tapping systems by which the crop from Hevea is obtained. Attention was directed by Evan Guest, of the Rubber Research Institute of Malaya, to the confusion and ambiguity which existed because different centres had developed their own nomenclature without plan, and his suggested scheme, modified by the co-operation of others, has now been accepted ( $J$. Rubber Research Inst. Malaya, $9,142-170 ; 1939: 10,16-33 ; 1940)$. This will mark a great advance in co-ordination of scientific records of yields from Hevea, for the fundamental factor, namely, intensity of tapping, is simply and accurately brought into the required prominence.

First the type of cut is identified by an initial letter, followed by the figure expressing the fraction of the tree circumference which is covered. Then the 